\title{
IbM BAGI PETAMBAK UDANG TRADISIONAL DI DESA MASARAN, KECAMATAN BANYUATES, KABUPATEN SAMPANG, YANG GULUNG TIKAR AKIBAT KASUS KEMATIAN UDANG YANG TERUS MENERUS
}

\section{IbM FOR TRADITIONAL SHRIMP FARMERS IN MASARAN VILLAGE, BANYUATES DISTRICT, SAMPANG REGION, THAT CAPITAL LOSTED BY SHRIMP DEAD CASES CONTINUOESLY}

\author{
Sudarno, Gunanti Mahasri dan Kismiyati \\ Fakultas Perikanan dan Kelautan Universitas Airlangga \\ Kampus C Mulyorejo - Surabaya, 60115 Telp. 031-5911451
}

\begin{abstract}
Tiger shrimp (Penaeus monodon Fab) is one of the economically important shrimp, until 1992 became the most important of non petroleum export commodity from fishery sector. Since the end of 1993 up to now, the Penaeus monodon Fab death level has been relatively high and due to this circumstance have been caused many ponds collapsed so that the shrimp production was dramatically declined for year by year.

Banyuates District is one of the Sampang Region areas which have big fisheries potential, aspecially for the breakist water pond, that the topest as the other district. There are a lot of shrimp dead cases until now. But, so that $80 \%$ of breakist water pond were broken and not operational.

The objective of this societies service activities is applicated a new shrimp culture technology with traditional plus Imuno-Biocirculation System. Imuno-Biocirculation System (SI-PBR) for increases the shrimp harvest at Candi District Region of Sidoarjo, at May until Desember 2013. The method using in the activity were socialitation/counseling, dempond and guiding to application of the SI-PBR model in one periode. Monitoring and evaluation about this result were done in one month after the activity ending.

This result showed that a positive indication. There was the knowledges of the farmer in ceases by socialization, it also applicated a model in the right method for shrimp culture. There were also showed that the SI-PBR model can in ceased the shrimp harvest from 272,43 kg/ha to 854,66 kg/ha, it means was increased $313 \%$.

The conclution of this activity is the SI-PBR model can increased the shrimp harvest and can applicates in more larges area in Sidoarjo Region.
\end{abstract}

Keywords : Tiger Shrimp, Idle Ponds, Traditional Plus, Imuno-Biosirculation, Harvesting

\section{Pendahuluan}

Salah satu jenis udang laut yang mempunyai nilai ekonomis penting adalah Udang windu (Penaeus monodon Fab). Sampai sekarang udang windu masih merupakan primadona komoditas eksport non migas dari sektor perikanan. Udang Vannamei yang masuk ke Indonesia diharapkan dapat menggantikan kedudukan udang windu masih belum dapat diharapkan. Hal ini menunjukkan bahwa usaha budidaya udang windu ini masih mempunyai prospek yang cerah dan merupakan andalan dari sektor perikanan. Nilai eksport udang windu pada dekade sepuluh tahun yang lalu tepatnya pada tahun 1992 mencapai 1200 U\$ Dolar, dan saat itu Indonesia termasuk empat besar dunia negara pengeksport udang windu. Sebagai sumber protein udang windu juga mempunyai peran yang besar dalam pemenuhan protein hewani asal ikan, karena nilai gizinya yang tinggi (Rosati, 1994). Mulai tahun 1993 produksi ini menurun sebesar $70 \%$ yang dikarenakan terjadi kasus kematian udang windu baik di tambak maupun di Hatchery, yang dikarenakan oleh serangan penyakit maupun penurunan kualitas air. Kasus kematian ini berlanjut hingga sekarang, akan tetapi pada tahun 1997 dan 1998 produksi udang windu baik benur maupun ukuran konsumsi udang terjadi peningkatan hingga 30\% dengan harga jual mencapai Rp.170.000,- per kg size 30 ekor. Untuk selanjutnya kondisi produktivitas udang windu menunjukkan grafik yang naik turun, dan berbagai trobosan untuk mengatasi sudah banyak dilakukan (Taslihan, dkk. 2005). Tingkat keberhasilan budidaya udang windu sangat ditentukan oleh usaha pembenihan udang yang dilakukan oleh Panti Pembenihan (Hatchery), Panti Pembenihan Skala Rumah Tangga (Backyard) maupun skala besar dalam 
menyediakan benur udang yang berkualitas dan bebas penyakit.

Kecamatan. Banyuates merupakan salah satu kecamatan yang mempunyai potensi besar dalam sektor perikanan, baik perikanan tangkap maupun budidaya. Luas pertambakan di Kabupaten Sampang adalah sekitar 3.765 hektar, yang sebagian besar terletak di derah pesisir (pantai). Produksi udang sebelum terjadi kasus kematian udang tahun 1993 secara nasional mencapai 7.34 ton per hektar per tahun. Adanya kasus kematian udang menyebabkan penurunan produksi hingga $82 \%$ menjadi rata-rata 1,67 to per hektar per tahun. Salah satu desa di Kabupaten Sampang, yang merupakan daerah pertambakan dan mempunyai potensi yang besar dalam bidang perikanan adalah Desa Masaran, Kecamatan Banyuates.

Selama ini para petambak di Desa Masaran tersebut dalam mengelola tambaknya masih menggunakan cara yang turun temurun dari nenek moyangnya. Sehingga hasil panen yang diperoleh hingga sampai sekarang masih jauh dari target, bahkan sejak adanya kasus kematian udang sejak tahun 1994, banyak petambak tersebut yang gulung tikar, karena gagal panen beruntun sampai saat ini. Penghasilan para petambak ini sangat rendah, dengan rata-rata penghasilan hanya mencapai 1,2 juta pada tiap periode panen yaitu selama 3 - 3,5 bulan. Di dalam perjalanan waktu dengan kondisi perekonomia yang semakin buruk tersebut, para petambak berganung dengan $\mathrm{CV}$. Putri Mandiri Grup, dimana manajemn usaha tambaknya di bawah CV tersebut mulai tahun 2001.

Untuk menanggulangi penyebab rendahnya hasil panen udang tersebut, dapat dilakukan dengan sentuan teknologi pada tambak tradisional menjadi tradisional plus dengan System Imuno Bio-Resirkulasi (SIPBR). Sistem ini merupakan pengembangan dari system tradisional plus, dengan aplikasi imunisasi pada benih yang akan ditebar dan penerapan filter biologis dari ikan bandeng yang diterapkankan pada design atau layout tambak yang ada. Menurut Mahasri (2007), Salfira (1998) dan Rukyani (1996), yang menyatakan bahwa dengan imunostimulan dapat meningkatkan tingkat kelulushidupan (SR) udang windu di tambak hingga $86 \%$. Selanjtnya oleh Mahasri (2001), Chamratkhakool (1996) dan Subandriyo (1997) bahwa dengan filter biologis dari ikan bandeng pada tambak tradisional plus dapat meningkatkan hasil panen hingga $82 \%$.

Penerapan teknologi dalam usaha memberikan hasil yang terbaik dan memenuhi target panen, hal ini disebabkan karena suatu teknologi harus disesuaikan dengan daya dukung lingkungan yang selalu mengalami perubahan (Subandriyo, 1997). Kematian udang yang terjadi pada usaha budidaya perikanan umumnya disebabkan karena adanya serangan penyakit, lingkungan yang kurang mendukung dan teknologi yang diterapkan tidak sesuai. Selanjutnya dikatakan untuk mencegah masuknya pencemaran lingkungan ke dalam tambak dapat diatasi dengan menggunakan system budidaya perikanan dengan resirkulasi. Pada system ini, air yang telah digunakan dan sudah mengalami penurunan mutu diolah kembali (dengan resirkulasi) pada petakan tertentu, sehingga dapat berdayaguna kembali.

Untuk mendapatkan kualitas air yang optimal pada budidaya perikanan dengan system resirkulasi, dapat dilakukan dengan menggunakan filter biologis atau dengan bahan kimia. Penggunaan bahan kimia dapat menyebabkan dampak negatif yaitu dapat menyebabkan resistensi dan menimbulkan residu pada tubuh udang. Anonimus (1996) dan Subandriyo (1997) mengatakan bahwa filter biologis yang dapat digunakan adalah dengan ikan bandeng, ikan nila, kerang hijau (Mytilus sp.), dan rumput laut (Ulva pertusa). Selanjutnya dikatakan bahwa dengan rumput laut dapat meningkatkan carrieng capacity system sebesar 36\%, serta dapat meningkatkan kelulushidupan (SR) udang windu dari $61 \%$ menjadi $86 \%$. Mahasri (2001) mengatakan bahwa filter biologis ikan bandeng sebanyak 1000 ekor dalam petak dengan luas $1000 \mathrm{~m}$ persegi (1 ekor per meter persegi) dapat meningkatkan kelulushidupan (SR) hingga $82 \%$.

Penggunaan imunostimulan pada budidaya udang windu sudah banyak dilakukan untuk meningkatkan daya tahan dan dapat meningkatkan kelulushidupan udang. Imunostimulan dari dinding sel bakteri dapat meningkatkan system pertahanan tubuh udang stadia benih dan meningkatkan kelulusan hidup benih udang hingga 93\% Sedang Aksono (2005) mengatakan bahwa imunostimulan dari protein VP 28 virus WSSP dapat meningkatkan kelulushidupan udang hingga $100 \%$ dan Mahasri (2007) dalam hasil penelitiannya mengatakan bahwa imunostimulan dari protein membran imunogenik Zoothamnium penaei dapat meningkatkan kelulushidupan udang dari $10 \%$ hingga mencapai $96 \%$.

Budidaya udang dengan System Imuno-Probiosirkulasi (SI-PBR), merupakan upaya meningkatkan hasil panen udang dengan 
penerapan imunisasi dan filter biologis dengan ikan bandeng. Sistem ini merupakan gabungan antara penggunaan imunostimulan pada benih udang sebelum ditebar untuk meningkatkan daya tahan tubuh udang. Imunostimulan yang digunakan adalah adalah imunostimulan dari protein membran imunogenik MP Zoothamnium penaei untuk mencegah serangan penyakit zoothamniosis (Mahasri, 2007). Disamping system ini juga menggunakan probiotik untuk mempertahankan kualitas air. Gunarto, dkk. (2006), Shou Jun, et al. (2005) dan Maeda, et al. (2000) dan Sharift, et al. (2001) mengatakan bahwa penggunaan probiotik dengan berbagai jenis bakteri pengurai bahan organik pada budidaya udang windu sudah banyak dilakukan untuk meningkatkan kelulushidupan udang hingga $86-93 \%$.

Penggunaan filter biologis ikan bandeng 1 ekor per meter persegi dalam sistem ini dilakukan pada petak resirkulasi yang sudah didesign pada petakan tambak udang. Tujuan dari filter ini adalah untuk menyeimbangkan biomassa plankton, mengurangi senyawa nitrit dan amoniak, karena ikan bandeng dapat mengakumulasi senyawa tersebut dalam tubuh udang, sehingga tidak terjadi pembusukan di dalam tambak. Hasil penelitian Mahasri (2007) menunjukkan bahwa dengan system imuno bioresirkulasi dapat meningkatkan kelulushidupan udang windu dari $40 \%$ menjadi $82 \%$ pada tambak tradisional plus. Bertitik tolak dari analisis situasi di atas maka sangat perlu diterapkan teknologi tepat guna pada budidaya udang di tambak milik CV. Putri Mandiri Grup dengan system tradisional plus dengan Sistem Imuno-Probiosirkulasi, dengan tujuan meningkatkan hasil panen udang windu bagi petambak di Desa Masaran tersebut.

\section{Materi dan Metode}

Berdasarkan identifikasi permasalahan pada mitra, maka permasalah utama yang harus segera ditangani adalah: 1) Permasalahan tambak yang rusak dan tidak operasional,

2) Hasil Panen rendah, sehingga gulung tikar, 3) Penghasilan petambak yang sangat rendah dan 4) Rendahnya pengetahuan dan keterampilan dalam melaksanaka usaha tambak.

Metode pelaksanaan kegiatan ini terdiri dari tiga tahap yaitu : (1) Tahap pembuatan petak SI-PBR dan petakan pemeliharaan udang, (2) Tahap penyuluhan dan peragaan serta (3) Tahap penerapan budidaya udang di tambak tradisional dengan sistem biofilter dengan ikan bandeng.

Tahap pembuatan Petak SI-PBR.
Pembuatan Pertak Resirkulasi dilakukan langsung di tambak milik CV. Putri Mandiri Grup. Proses pembuatannya meliputi : (1) Penyedian lahan dan petakan tambak, (2) Penyiapan dan pembuatan filter biologis dari ikan bandeng yang sesuai dengan fungsinya, (3) Penyediaan imunostimulan.

Tahap penyuluhan dan peragaan.

Penyuluhan dan peragaan cara pembuatan petak SI-PBR dengan biofilter ikan bandeng dilakukan dengan mengunjungi petambak yang bergabung di CV-PMG di Desa Masaran, Kecamatan Banyuates, Kabupaten Sampang (door to door). Metode ini dilaksanakan dengan pertimbangan efektivitas dan efisiensi kerja tim pelaksana pengabdian kepada masyarakat dan kemudahan pihak khalayak sasaran untuk menerima pengetahuan tentang SI-PBR. Adapun materi penyuluhan meliputi tentang budidaya udang windu SI-PBR dengan biofilter ikan bandeng dan petak tandon serta patak pemeliharaan. Tahap peragaan secara langsung dilakukan di lokasi tambak sehingga khalayak sasaran dapat lebih memahami dan mengerti materi penyuluhan dengan baik sehingga dapat mengoperasikannya di lapangan. Disamping itu juga dilakukan peragaan tentang teknik imunisasi pada benih udang.

Tahap Penerapan Budidaya Udang Dengan System SI-PBR.

Pada tahap ini merupakan tahap penerapan langsung budidaya udang windu dengan Sistem SI-PBR di tambak. Tahap ini diawali dengan pengecekan ulang petakan SI-PBR dengan filter biologi yang digunakan adalah ikan bandeng. Penyediaan benih dilakukan oleh tim penyuluh, dalam hal ini tim penyuluh bersifat sebagai pembimbing selama satu siklus pemeliharaan udang yaitu kurang lebih selama 4 bulan. Selama masa pemeliharaan udang satu siklus, kegiatan yang dilakukan adalah melakukan pengontrolan terhadap petak sirkulasi, kualitas air dan kesehatan dan pertumbuhan udang sebagai data pendukung penilaian tingkat keberhasilan SI-PBR yang diterapkan.

\section{Hasil dan Pembahasan}

Kegiatan ini merupakan kegiatan pengabdian kepada masyarakat yang menerapkan Sistem Imunobio-Sirkulasi (SIPBR) yang merupakan teknologi tepat guna yang diterapkan dalam budidaya udang baik windu maupun vannamei, dengan menggunakan imunostimulan, bio filter dan sirkulasi air tambak. Menurut Mahasri (2007) mengatakan bahwa imunostimulan dari Zoothamnium penaei dapat meningkatkan tingkat 
kelulushidupan udang yang dipelihara dari 10 hingga $81 \%$. Sedangkan biofilter yang dapat diperankan oleh ikan bandeng (Chanos chanos Forsk) atau rumput laut dapat digunakan untuk menyeimbangkan bio massa (plankton) di air tambak agar tetap dalam kondisi seimbang. Selanjutnya dikatakan bahwa sirkulasi air merupakan salah satu tindakkan yang mutlak harus dilaksanakan dalam kegiatan budidaya udang untuk mempertahankan kualitas air.

Penerapan SI-PBR ini akan didapatkan hasil panen udang yang berkualitas dan bebas penyakit. Air tambak akan tetap dalam kondisi yang berkualitas, sehingga penyakit tidak muncul selama budidaya dan udang dapat tumbuh dengan baik dan sehat. Di Thailand biosirkulasi ini sudah diterapkan pada tambak udang windu dan dapat meningkatkan produksi hingga 2 ton per hektar (Chifumi, et al., 2005), di China dapat meningkatkan tingkat kelangsungan hidup (SR) hingga $81 \%$ dan di India dapat meningkatkan produksi hingga 3 kali jika dibandingkan dengan sistem budidaya intensif. Menurut Mahasri (2000), menyatakan bahwa aplikasi SIBR pada tambak tradisional plus dapat meningkatkan tingkat kelulushidupan (SR) udang windu di tambak hingga $86 \%$. Tahapan dari penerapan model tambak pola tradisional plus SI-PBR ini mencakup : penyediaan lahan dan konstruksi tambak, persiapan tambak,pembuatan petak tandon dan filter biologis, manajemen kualitas air , penyediaan benur, pemeliharaan udang, pemberantasan hama dan penyakit, pemanenan dan manajemen pasca panen.

Konstruksi tambak dan tata letak tambak menyesuaikan keadaan yang ada di lokasi, sebab apabila harus merubah akan memerlukan waktu yang lama, sehingga di kawatirkan waktu penelitian tidak cukup. Bentuk petakan tambak yang digunakan untuk penerapan ini adalah empat persegi panjang sebanyak dua petak dengan luas masing-masing \pm 1.2 ha, kedalaman $\pm 100 \mathrm{~cm}$. Tanggul dan dasarnya terbuat dari tanah lempung berpasir, lebar tanggul utama $\pm 1,5 \mathrm{~m}$ dengan dasar tambak sedikit miring kearah pembuangan air.

Bentuk petak tendon yang digunakan adalah empat persegi panjang luas $\pm 220 \mathrm{~m} 2$. Ukuran petak tendon tersebutmasuk sangat kecil jika dibendingkan dengan luas petak pemeliharaan. Ukuran ideal petak tendon ini adalah 30 - 50\% dari luas petak pemeliharaan. Kecilnya petak tendon yang dipergunakan tsb dikarenakan dalam penelitian aksi ini prinsipnya adalah menggunakan petak-petak yang sudah tersedia, sebab apabila akan merubah bentuk dan ukuran petak-petak yang ada dan disesuaikan dengan teknologi, maka akan memerlukan waktu yang lama dan biaya yang sangat besar. Disain tataletak tambak pola tradisional dengan SI-PBR secara lengkap disajikan pada Lampiran 1.

Persiapan tambak dimulai dengan pengeringan tanah hingga kering selama sekitar satu bulan, kemudian dilakukan pengapuran dosis 1 ton/ha dan pembalikan tanah (penyingkalan) yang dilanjutkan dengan pemberantasan hama dan penyakit dengan menggunakan THIODAN. Pupuk yang digunakan adalah urea dan TSP dengan dosis masing-masing 200 dan $100 \mathrm{~kg} / \mathrm{ha}$. Perbaikan tanggul dan kedhok teplok dilakukan untuk menutup kebocoran dan perembesan air, kemudian dilanjutkan dengan pembuatan caren, pembersihan kotoran dan pengaturan kemiringan lantai sehingga memudahkan dalam sirkulasi air.

Pembuatan tendon filter biologis juga diawali kegiatan seperti pada persiapan petak pemeliharaan. Filter biologis yang digunakan adalah ikan bandeng dengan padat penebaran 5 ekor/m2. Pada kegiatan ini digunakan 1.250 ekor bandeng. Pengisian air dilakukan dua minggu sebelum dimasukkan ke petak pemeliharaan udang windu. Fungsi ikan bandeng adalah untuk memanfaatkan biomassa fitoplankton dan bahan terurai yang melimpah, mendaur ulang nutrient dan menjaga perkembangan fitoplankton agar stabil, dan untuk mengurangi beban lingkungan yang berasal dari partikel organic dan nutrien dalam air limbah. Pengairan petak pemeliharaan dilmulai dari pemasukan air dari petak tandon, dimasukkan ke petak pemeliharaan dengan melalui pintu dari kayu. Imunostimulan yang digunakan ada.lah imunostimulan dari Zoothamnium penaei yang dapat meningkatkan daya tahan tubuh terhadap serangan penyakit. Imunostimulan ini digunakan untuk benur udang sebelum ditebar, dengan cara direndam dengan dosis 300 mikrogram per liter

Penebaran benih dilakukan setelah air dalam petak pemeliharaan mencapai ketinggian $\pm 60 \mathrm{~cm}$ dan sudah didiamkan selama dua hari ( \pm 48 jam). Benih yang ditebar dapat berupa benur (PL-11) ataupun yang sudah berukuran glondongan. Penggunaan imunostimulan dilakukan pada tiap-tiap kantong plastik pada saat pengepakan untuk transportasi dengan dosis tiga tetes per kantong. Untuk kegiatan ini digunakan benih yang berukuran glondongan dan diambil dari pengusaha glondongan di sekitar lokasi penelitian. Hal ini bertujuan untuk mengurangi tingkat stress benih, karena kondisi perairan yang tidak terlalu jauh berbeda. Dua 
hari sebelum benih ditebar dilakukan pemberian biocyn pada air tambak dengan dosis $1 \mathrm{~kg} / \mathrm{ha}$, yang bertujuan untuk menjaga kualitas air selama pemeliharaan. Untuk selanjutnya biocyn diberikan tiap dua minggu sekali, dengan dosis $1 \mathrm{~kg} / \mathrm{ha}$. Penebaran benih udang dilakukan pada pagi hari, dengan padat tebar 16 rean/ha.

Sirkulasi air dilakukan setelah udang berumur satu bulan di petak pemeliharaan, dengan tujuan untuk mengurangi stress udang. Sirkulasi dilakukan dengan cara tiap hari mengurangi sebanyak $10-20 \%$ dikeluarkan melalui pintu pengeluaran. Sambil mengeluarkan air pemasukan air dari petak tandon juga dilakukan sebanyak air yang dikeluarkan. Sirkulasi air ini ditujukan untuk menggantikan air agar air selalu dalam keadaan baik dan bersih serta sebagai pengganti aerasi yang umumnya dengan menggunakan kincir air. Arah sirkulasi air ini disajikan pada Lampiran 1 dan hasil lengkap pemantauan kualitas air pada tambak disajikan pada Tabel 1 .

Tabel 1. Hasil Rata-rata Pemeriksaan Parameter Kualitas Air selama Pemeliharaan Udang

\begin{tabular}{|l|c|}
\hline \multicolumn{1}{|c|}{ Parameter } & Kisaran Nilai \\
\hline Kecerahan ( Cm ) & $30-35$ \\
Suhu ( oC ) & $27-32$ \\
Salinitas ( ppt ) & $13-21$ \\
pH & $7.5-8.5$ \\
Oksigen terlarut ( ppm ) & $4-6$ \\
Nitrit ( ppm ) & $2-5$ \\
Carbondioksida & $0.1-0.2$ \\
\hline
\end{tabular}

Tabel 1 menunjukkan bahwa parameter kualitas air tambak selalu dalam kisaran optimalisasi pertumbuhan udang. Hal ini menunjukkan bahwa petak tandon dengan filter biologis dari ikan bandeng dapat menghasilkan kualitas air yang optimal.

Pakan yang digunakan adalah pakan buatan pabrik, diberikan sebanyak empat kali sehari (24 jam). Dosis dan ukuran pakan disajikan pada Tabel 2.

Pertumbuhan udang sejak awal hingga umur dua bulan relatif normal dan merata serta menunjukkan adanya peningkatan seperti disajikan pada Tabel 3.

Pemantauan penyakit dilakukan setiap hari mulai udang berumur satu bulan di tambak, dengan melihat gejala klinis yang Nampak dan dengan pengambilan sampel. Selama pemeliharaan udang, tidak ditemukan adanya penyakit yang menyerang

Padat penebaran bandeng adalah satu rean/ha, sehingga dalam penelitian ini bandeng yang ditebar sebanyak 5.000 ekor. Dalam hal ini bandeng berfungsi untuk memanfaatkan ganggang dan plankton yang berlimpah dan berfungsi sebagai filter biologis seperti pada petak tandon. Dengan sistem ini ternyata sangat efektif untuk menjaga kelangsungan hidup udang dan pertumbuhan udang menjadi normal kembali. Pertumbuhan udang pada umur 90 hari ukuran udang sudah mencapai 40 - 45 ekor per kilogram (size 40-45).

Panen udang dilaksanakan setelah udang berumur kurang lebih tiga bulan di

Tabel 2. Cara, Dosis dan Waktu Pemberian Pakan

\begin{tabular}{|l|l|c|c|}
\hline \multicolumn{1}{|c|}{ Ukuran Udang } & \multicolumn{1}{c|}{ Jenis Pakan } & Dosis $(\%) \mathrm{BB} /$ hari & Waktu Pemberian \\
\hline PL $15-$ PL 20 & Flake & $25-50$ & $4 \mathrm{x}$ \\
< I gram & Crumble & $25-50$ & $4 \mathrm{x}$ \\
$1-5$ gram & Pelet $\Phi 1 \mathrm{~mm}$ & $25-50$ & $4 \mathrm{x}$ \\
$5-6$ gram & Pelet $\Phi 1.5 \mathrm{~mm}$ & $15-25$ & $4 \mathrm{x}$ \\
$11-15$ gram & Pelet $\Phi 2.5 \mathrm{~mm}$ & $8-15$ & $4 \mathrm{x}$ \\
$20-30$ gram & Pelet $\Phi 4 \mathrm{~mm}$ & $4-8$ & $4 \mathrm{x}$ \\
\hline
\end{tabular}

Tabel 3 Pertumbuhan Udang Selama Periode Pemeliharaan

\begin{tabular}{|c|c|}
\hline Hari ke- & Berat (gram) \\
\hline $0($ PL- 25/30) & $0.03-0.35$ \\
20 & $1.7-1.9$ \\
40 & $9.0-9.3$ \\
60 & $15.5-16.6$ \\
90 & $20-26$ \\
\hline
\end{tabular}


Tabel 4. Hasil Panen Udang Pada Petak Pemeliharaan

\begin{tabular}{|l|c|c|c|}
\hline No. & $\begin{array}{c}\text { Petak Pemeliharaan Udang } \\
\text { dengan SI-PBR (Kg/Petak) }\end{array}$ & $\begin{array}{c}\text { Petak Pemeliharaan } \\
\text { Kontrol }(\text { Kg/Petak) }\end{array}$ & $\begin{array}{c}\text { Petak Pemeliharaan } \\
\text { Bandeng (Kg/Pertak) }\end{array}$ \\
\hline I. & 791 & 269 & 566 \\
II. & 808 & - & - \\
III. & 932 & - & - \\
\end{tabular}

tambak dan udang sudah mencapai size 35 - 40 ekor per kilogram. Hasil panen udang dari ke tiga petak pemeliharaan dapat dilihat pada Tabel 4. Tingkat keberhasilan dari penerapan teknologi ini sangat tergantung dari keadaan tambak, lokasi tambak dan iklim/musim. Adapun kendala yang harus dihadapi dalam penerapan teknologi ini antara lain adalah : terlalu kecilnya petak tandon, sulitnya mendapatkan benih (glondongan) yang bermutu dan bebas penyakit serta sulitnya menahan penularan penyakit dari petak pemeliharaan lain. Sedangkan faktor-faktor yang mendukung keberhasilan dari penerapan teknologi ini antara lain adalah adanya kerjasama yang baik antara peneliti, petambak, penduduk sekitar dan instansi terkait.

Berdasarkan Tabel 4 di atas menunjukkan bahwa hasil panen udang windu pada tiap-tiap berturut-turut $791,808,93 \mathrm{Kg}$ per Petak, dengan rata-rata $884.33 \mathrm{~kg}$ dan ikan Bandeng $566 \mathrm{Kg}$. Jika dibandingkan dengan hasil panen pada tambak di sekitar kegiatan yang menunjukkan bahwa tiap petak rata-rata adalah 265,43 Kg per Petak. Hasil tersebut menunjukkan bahwa dengan menggunakan model budidaya udang pola tradisional plus dengan sistem SI-PBR dapat meningkatkan hasil panen dari $272.43 \mathrm{Kg}$. menjadi rata-rata $884.3 \mathrm{Kg}$ per petak dengan luas rata-rata $1 \mathrm{Ha}$. Jika dipersentasekan adalah sebesar 313\%.

Bertitik tolak dari hal-hal tersebut di atas maka model budidaya udang pola tradisional SI-PBR dengan filter dari bandeng sangat menguntungkan, karena walaupun juga terjadi serangan penyakit, tidak sampai mematikan dan masih dapat teratasi, tidak seperti tambak-tambak di sekitar tambak percontohan.

Evaluasi hasil sosialisasi / penyuluhan yang dilakukan dengan cara mendatangi langsung pada petambak menunjukkan adanya peningkatan pengetahuan tentang model budidaya udang pola tradisional plus dengan Sistem BMP. Hal ini terbukti bahwa para petambak yang turut berperan serta dalam kegiatan ini sudah menerapkan pola tradisional plus dengan melakukan pengapuran dan pembuatan petak sirkulasi dengan filter biologi dengan ikan bandeng. Untuk hasil panen belum dapat dievaluasi karena sampai sekarang petambak masih proses pemeliharaan udang dan direncanakan panen pada bulan Februari 2014.

Berdasarkan hasil penerapan metode SI-PBR menunjukkan adanya peningkatan hasil panen udang hingga $376 \%$. Hasil evaluasi setelah kegiatan pengabdian kepada masyarakat selesai menunjukkan bahwa terdapat 4 dari 20 petambak yang menerapkan SI-PBR pada pemeliharaan udang, akan tetapi hasil panen belum dapat dilaporkan karena masa tanam satu periode adalah 3 bulan, sehingga belum saatnya panen.

\section{Kesimpulan}

Penerapan SI-PBR terbukti dapat meningkatkan daya tahan tubuh udang sehingga udang tidak terserang penyakit selama pemeliharaan

Petak sirkulasi dengan filter biologis dari ikan bandeng dapat meningkatkan dan mempertahankan kualitas air tambak pemeliharaan udang, sehingga selalu kondisi yang optimal untuk kehidupan udang windu.

Model budidaya udang pola tradisional plus dengan SI-PBR dapat meningkatkan hasil panen udang windu hingga $376 \%$, sehingga dapat direkomendasikan untuk diperluas penerapannya pada di kecamatan Banyuates, sampan, Madura khususnya dan di Indonesia pada umumnya.

Untuk menerapkan model budidaya pola tradisional plus dengan SI-PBR disarankan minimum menggunakan 3 petakan yaitu satu petak untuk petak tandon dengan filter biologis ikan bandeng. Dua petak berikutnya adalah untuk petak pemeliharaan udang.

Perlu pemantauan terhadap kesehatan udang secara rutin dan kualitas air selama penerapan model budidaya udang pola tradisional plus SIPBR untuk menjaga optimalisasi parameter kualitas air.

Daftar Pustaka

Aji, B., S. Ginting dan M. Cristina. 1998. Rezeki dari Si Bongkok. Kontan. No. 40.Tahun II.

Chifumi, Thongchai, Osamu \& Kurokura, 2005. Incentive to shifts in Water 
management systems by shrimp culturist in Shouthern Thailand, Fisheries Science, Vol 71, Issue 4, Pages 791-8

German, M, Eduardo U, Gasper S \& Elizabeth V.B, 2008. A Comparison of Larval production of the Nothern scallop, Argopertempurpuratus, in closed and recirculating Culture system, J.Aquaeng, Vol 38, 11.004.

Haryanti. 2004. Broodstock Udang Vannamei. Makalah pada Seminar Sehari Perudangan Nasional: Upaya Mengatasi Problem Teknis dan Pemasaran Udang Melalui Standarisasi Budidaya.

KKP, 2013. Strategi pengembangan perikanan budidaya dalam menghadapi daya saing, materi disampaikan pada Seminar Nasional BKPIM 2013.

Liao, I. C. 2000. Aquaculture Development: Challenges for the $21^{\text {st }}$ Century.

Maeda, M, K.Nogami \& Y. Kotami, 200. Manipualtion of microbiol communities for Improving the Aquaculture Environment, J.Aquaculture, $02.035:$ 192-8

Mahasri,G, 2007. Kemampuan ikan Bandeng sebagai Filter Biologi dalam Menekan Pertumbuhan Ciliata Patogen pada Tambak, LPPM Universitas Airlangga, Surabaya

Moss, S. M. and S. M. Arce. 2003. SPF Defined: Pathogen - Free Status of Shrimp Limited. Global Aquaculture Advocate.

Rosati, R, 1994, Indonesian Shrimp Industry Status and Development Project, Puslitbang Perikanan, Jakarta

Rosy, L.J, Valeriano, L.C.Jr \& Taizos, 2004. Water quality and plytoplankton Stability in Response to application frequency of Bioargumentation agent in Shrimp pond. In Press, Accepted Manuscript, Available on line Aquaculture Enginering doi 10.10.J.Aqua Eng.01.001 page :200-5
Rukyani, A, 1994, Jenis Penyakit Udang, Makalah Pertemuan Aplikasi Paket Teknologi Pertanian, BIP Lampung, 9 - 11 Januari 1994.

Sharift, M, F.M Yosoff, T.N Devaraja \& Srinivasan R, 2001. The Effectiveness of a commercial microbiol product in Poorly prepared tiger shrimp Penaeus monodon ponds, Aquaculture Research Vol 32 Issue $3: 181-7$

Subandriyo, 2001, Budidaya Udang dengan Sistem Resirkulasi dan Masalahnya, Pt. Charoen Pokphand Indonesia, Medan.

Supito, A. Taslihan dan M. Murdjani. 2004. Solusi Pencegahan White Spot pada Pembesaran Udang Windu di Tambak Sidoarjo dan Gresik Dengan Penerapan BMP Balai Besar Pengembangan Budidaya Air Payau

Syarief, H dan Faisol Humaidi, 2006, Budidaya Udang Air Payau Sistem Tradisi Berbasis Organik di Sidoarjo, Makalah Pertemuan Penerapan Teknologi BMP untuk Mendukung Revitalisasi Budidaya Udang, DKP - ACIAR, Surabaya 6 - 8 Maret 2006. Hal 1 - 20.

Taslihan, A, Supito, Erik Sutikno, R.B. Callinan, 2005, Teknik Budidaya Udang Secara Benar, Balai Besar Pengembangan Budidaya Air Payau, Ditjen Perikanan Budidaya, Jakarta.

Warta Pasar Ikan. 2005. Warta Pasar Ikan. Direktorat Jenderal Perikanan. Departemen Kelautan dan Perikanan. Jakarta.

Wu Xiongfei \& Z. Zhidong, 2005. Closed recirculating system for shrimpmoluscha polyculture, J.oceano-limno, Vol 24 No 4 : 461-8

Yoram, A, 2006. Biofilters : The need for a new Comprehensive Approach, J.Aquaeng, Vol 34 : 172-8 